\title{
Prevalence of intestinal parasites and associated risk factors among HIV/AIDS patients attending at anti-retroviral treatment (ART) clinic at Mizan-Tepi university teaching hospital, southwest Ethiopia
}

Mengistu Abayneh ( $\sim$ menge.abay@gmail.com )

Mizan Tepi University

Tadesse Duguma

Mizan Tepi University

\section{Research Article}

Keywords: Prevalence, Intestinal parasite, HIV/ AIDS, Southwest district, Ethiopia

Posted Date: April 11th, 2022

DOI: https://doi.org/10.21203/rs.3.rs-1304850/v2

License: (c) (1) This work is licensed under a Creative Commons Attribution 4.0 International License.

Read Full License 


\section{Abstract \\ Background}

Intestinal parasitic infections are still very common, especially in areas where immune-compromised patients like HIV/AIDS patients are high prevalent. Therefore, the aim of this study was to assess the prevalence of intestinal parasite and risk factor among HIV/ AIDS patients attending ART clinic in MizanTepi university teaching hospital, Southwest Ethiopia.

\section{Method}

A cross -sectional survey was conducted from July to September, 2021. A total of 191 study subjects were participated in this study. A structured questionnaire was used for collecting socio-demographic and risk factors data. Stool sample was collected and processed using direct wet mount, formol-ether concentration technique and modified Ziehl-Neelson staining techniques. Data was analyzed using statistical package for social sciences (SPSS) Version 25 software and logistic regressions were applied to assess any association between explanatory factors and outcome variables.

\section{Result}

From a total of 191 stool samples, 67 (35.1\%) were positive for intestinal parasites. The prevalence of intestinal parasites among patients on-ART was 31.5\% (45/143) and 45.8\% (22/48) among ART naïve group. Entamoeba histolytica/dispar (7.7\%) and (12.5\%) and Giardia lamblia (7.0\%) and (10.4\%) was the most predominant parasites detected both in ART and ART naïve groups $(p>0.05)$. Drinking untreated water $(A O R=0.13 ; 95 \% \mathrm{Cl}: 0.016-1.012)$, consuming raw food $(A O R=0.23 ; 95 \% \mathrm{Cl}: 0.025-2.108)$, eating unwashed raw vegetables $(A O R=2.26 ; 95 \% \mathrm{Cl}: 1.052-4.843) ; \mathrm{CD}_{4}$ count $<200$ cells $/ \mathrm{mm}^{3}(\mathrm{AOR}=0.22$; $95 \% \mathrm{Cl}: 0.062-0.798), \mathrm{CD}_{4}$ count $200-500 \mathrm{cells} / \mathrm{mm}^{3}$ (AOR $\left.=0.40 ; 95 \% \mathrm{Cl}: 0.195-0.811\right)$, WHO stage II $(A O R=0.30 ; 95 \% \mathrm{Cl}: 0.156-0.589), \mathrm{WHO}$ stage III (AOR $=0.32 ; 95 \% \mathrm{Cl}: 0.108-0.917)$ and viral load $\geq 150$ copies $/ \mathrm{ml}(\mathrm{AOR}=0.44 ; 95 \% \mathrm{Cl}: 0.220-0.873)$ were showed significant association with prevalence of intestinal parasite.

\section{Conclusion}

In this study, higher rate of intestinal parasitosis were associated with hygienic practices like drinking untreated water, consuming raw food and eating unwashed raw vegetables and with some clinical findings such as lower CD 4 counts, increased viral load and being WHO stage II \& III. Therefore, public health measures and adherence to ART should be strengthened to improve the immune status and to reducing vulnerability of the patients for intestinal parasites. 


\section{Introduction}

Parasitic infections, particularly intestinal parasites are among the most widespread of human infections worldwide and are the main threat in developing countries, as it has been noticeably heightened with the coexistence of large burden of HIV/AIDS and malnutrition in the area. It is estimated that as much as $60 \%$ of the World's population is infected with intestinal parasites which may play a significant role in morbidity due to intestinal infections [1-3].

Gastrointestinal problem resulting from opportunistic parasitic infection in HIV and AIDS infected subject has dramatically decreased in countries where antiretroviral agents are widely available. However, in most African countries, where patients have access to ART, intestinal pathogens still represent a frequent cause of diarrhea, wasting and weight loss. Evidence shows that HIV-infected patients are the most vulnerable risk group for acquiring parasitic infection, and about $85 \%$ of AIDS patients die as a result of AIDS related infections, rather than due to the HIV infection itself. These opportunistic infections most commonly occur in the later stages of HIV infection when numbering of CD4 T cells has declined mostly $<200 \mathrm{~mm}^{3}$ [4-7].

Despite ART improving the quality of life and reducing the occurrence of opportunistic infection due to immuno suppression, malnutrition, poor waste management, ignorance (illiteracy), unhygienic sources of drinking water and depleted CD 4 counts among HIV/AIDS patients are the most common determinants of parasitic infection $[6,7]$.

Intestinal parasitic worm infections are transmitted to humans through soil contaminated by human faeces, mostly in areas where sanitation is poor. Infection leads to anaemia, vitamin A deficiency, stunted growth, malnutrition, intestinal obstruction and impaired development. The most commonly reported intestinal parasites are Ascaris lumbricoides, hookworms, Trichuris trichiuria, Giardia lamblia, Entamoeba histolytica and Schistosoma species are the most common intestinal parasites. Among those opportunistic pathogens, Isospora belle, Cryptosporidium parvum, Cyclospora cayetanenis and Microsporodia specie increasingly reported as causes of enteritis and as opportunistic pathogen in immune compromised individuals [8-11].

As Ethiopia is one of the developing countries in the world it is categorized under a high prevalence of parasitic infections. According to the studies, the average prevalence of parasitic infections was $39.6 \%$ [12-15]. The estimated pooled prevalence of intestinal

parasitosis in HIV/ AIDS patients was 39.2\% [16].The severity and magnitude of IP in HIV/ AIDS patients require attention and study, especially in the countries like Ethiopia where there was high HIV/AIDS and parasite prevalence. Therefore, this study was aimed to determine the magnitude of intestinal parasite among HIV / AIDS patient who are coming to ART clinic at Mizan-Tepi university teaching hospital, South Western Ethiopia. The finding will help to sensitize local and national responsible bodies as prerequisite for updating strategies in the prevention and control of intestinal parasitic infection among HIV/AIDS patients. 


\section{Methdology}

\section{Study Area and period}

This study was conducted in Mizan-Tepi university teaching hospital from July to September 30, 2021. Mizan-Tepi university teaching hospital is found at $591 \mathrm{Km}$, South west of Addis Ababa, capital city of Ethiopia. It is the second more than 139 bedded teaching hospitals in the Southwestern part of the country, providing services approximately for 5 million people from four zones such as BENCH SHEKO, KEFA, SHEKA and MAJANG as referral center. About 350 clients visit the hospital daily for different services and there were more than 750 HIV positive patients taking ART services.

\section{Study design and subjects}

A cross- sectional study design was conducted to determine the prevalence of intestinal parasites among HIV positive patients who are attending ART clinic in MTUTH south Western Ethiopia. Consecutive HIV/AIDS patients who come for ART services during study period were included. Those who are not willing to participate and those couldn't provide stool samples were excluded.

\section{Sample size and sampling technique}

The required sample size was calculated using single population proportion formula by assuming that confidence interval of $95 \%$, margin error of $5 \%$, and the prevalence of intestinal parasites among people with HIV/AIDS (p) as 13.9\% [17], which is reported in previous study in Ethiopia.

Therefore: $n=\underline{(Z \alpha / 2)^{2} p(1-p)}$

$d^{2}$

Therefore: $\mathrm{n}=(1.96)^{2} \times 0.139(1-0.139)=\mathbf{1 8 4}$.

$(0.05)^{2}$

By assuming 4\% non-respondent rate, the final sample size for this study was 191 .

Data Collection

\section{Social-demographic data}

During implementation of data collections, the study subject was asked for their willingness in participation of the study. A structured questionnaire was utilized to collect socio-demographical (age, sex, residence, marital status, educational status) and other risk factors data such as hand washing practice, habit of consuming raw food, own domestic animals, availability and usage of latrine, shoe wearing habits, source and treatment of water for drinking. Patients were also asked for complaints of diarrhea. Data on WHO stage of HIV, viral load and level of CD $4+T$ cell count and antiretroviral treatment (ART) status was obtained from patients' medical records. 
A single fresh stool was collected with a labeled stool cup following standard procedures by laboratory technologist who worked at the ART clinic. The patients were provided with appropriate specimen container and applicator sticks to bring sufficient amount of stool specimen. Each sample were labeled with specific code number, and transported to the laboratory within 30 minutes of collection for parasitological analysis.

\section{Sample processing}

Then stool sample was examined both macroscopically and microscopically. Macroscopically its appearance was observed while microscopically it was examined using direct saline and iodine wet mount smear preparation, formol- ether concentration and modified Ziehl- Neelson technique [18, 19]. During microscopic examination of intestinal parasite their diagnostic stage was identify based on their shape, color and motility.

\section{Data Analysis}

Data were entered into SPSS Version 25 software for analysis. Frequency distributions and descriptive statistics such as the number and percent of intestinal parasites in relation to different variables were determined. Bivariate and multivariate analyses were performed to assess the association or crude and adjusted odd ratio of parasitic infections with the independent variables. A statistical test result was declared as significant when its $P$ value was less than 0.05 and crude and adjusted odds ratios with $95 \%$ confidence intervals $(\mathrm{Cl})$ were reported.

\section{Result}

\section{Socio-demography of the study subject}

A total of 191 subjects were participated in this study. Of these, $113(59.2 \%)$ were females and $89(46.6 \%)$ were age group of 35-50 years. Majority, $103(53.9 \%)$ and $133(69.6 \%)$ of study participants were urban residence and married, respectively. About $65(34.0 \%)$ of the study participants were complete their primary school and $44(23.0 \%)$ were working as house wives (Table- 1 ).

\section{Intestinal parasites among HIV/AIDS patients with ART and ART naïve group}

In this study, a total of 191 stool samples were tested for the detection of intestinal parasites (IPs). Of these samples, $143(75.0 \%)$ of them were taken from HIV/AIDS patients who were on-ART and the rest 48 (25.0\%) were taken from ART naïve group. Accordingly, the overall prevalence of IPs was 67 (35.1\%). The prevalence of IPs among HIV/AIDS patients who were on-ART was 45 (31.5\%) and 22 (45.8\%) among ART naïve group. The distribution of intestinal parasites was not statistically significant differences between ART and ART naïve group $\left(X^{2}=3.256\right.$; $P$ - value $\left.>0.05\right)$. Entamoeba histolytica/dispar $(7.7 \%)$ and $(12.5 \%)$ and Giardia lamblia (7.0\%) and (10.4\%) was the most predominant parasites detected in 
HIV/AIDS patients who were on-ART and ART naïve group, respectively. The prevalence of opportunistic intestinal parasites among ART and ART naïve group were $1.4 \%$ and $4.2 \%$, respectively for Cryptosporidium spps and $2.1 \%$ of Isospora belli were detected only in ART naïve group (Table-2).

\section{Prevalence of intestinal parasites in relation with Socio- demographic characteristics of study participants}

In this study, analysis with binary logistic regression showed that, place of residence and marital status of the study participants were identified as the major socio-demographic determinants of intestinal parasite among HIV/AIDS patients. Being rural residence were 61\% (COR $=0.39 ; 95 \% \mathrm{Cl}$ : 0.205-0.755; $p$ value $=0.005)$ more likely to had intestinal parasite than those of urban residence and being single by marital status were almost 3.38 times (COR $=3.38 ; 95 \% \mathrm{Cl}$ : 1.202-9.488; $p$-value $=0.021)$ more likely to harbour intestinal parasite than married one. Other socio-demographic characteristics, such as sex, age and educational status were did not show association with intestinal parasitic infection (Table- 1 ).

\section{Intestinal parasites in relation with CD4 level, viral load, ART status and WHO stages}

In this study, after multivariate analysis, having CD 4 counts $<200$ cell $/ \mathrm{mm}^{3}$ and $200-500 \mathrm{cell} / \mathrm{mm}^{3}$, being WHO stage II and III and viral load $\geq 150$ copies $/ \mathrm{ml}$ were significantly associated with intestinal parasitic infection. As shown in Table-3, HIV/AIDS patients whose CD 4 counts $<200$ cell $/ \mathrm{mm}^{3}$ and $200-500$ cell $/ \mathrm{mm}^{3}$ are $78 \%(\mathrm{AOR}=0.22 ; 95 \% \mathrm{Cl}: 0.062-0.798 ; p$-value $=0.021)$ and $60 \%(\mathrm{AOR}=0.40 ; 95 \% \mathrm{Cl}: 0.195-$ 0.811; $p$-value $=0.011)$ more likely to be infected for intestinal parasite than those with CD4 counts $>500$ cell $/ \mathrm{mm}^{3}$. Concerning HIV/AIDS patients with viral load $\geq 150$ copies $/ \mathrm{ml}$ are $56 \%$ (AOR $=0.44 ; 95 \% \mathrm{Cl}$ : $0.220-0.873 ; p$-value $=0.019)$ more likely to have parasite than those who having viral load $<150$ copies $/ \mathrm{ml}$. Regarding WHO stage being Stage II and WHO stage III are 70\% (AOR $=0.30 ; 95 \%$ Cl: 0.156$0.589 ; p$-value $=0.001)$ and $68 \%(\mathrm{AOR}=0.32 ; 95 \% \mathrm{Cl}: 0.108-0.917 ; p$-value $=0.034)$ more likely to have parasite than those patients with WHO stage I (Table-3).

\section{Prevalence of intestinal parasites in relation with environmental and hygienic practices of study participants}

In this study, among those studied variables related with environmental and hygienic practices of study participants, drinking untreated water, consuming raw food and eating unwashed raw vegetables were significantly associated with intestinal parasitic infection among HIV/AIDS patients in the multivariate logistic analysis. Those HIV/AIDS patients who was drinking untreated water are $87 \%$ (AOR $=0.13 ; 95 \%$ Cl: $0.016-1.012 ; p$-value $=0.035)$ more likely to be infected with intestinal parasite than those whose drinking treated water. Those HIV/AIDS patients consuming raw food are 77\% (AOR $=0.23 ; 95 \%$ Cl: $0.025-$ 
2.108; $p$-value $=0.017)$ more likely to have parasite than those who have not consuming raw food. In addition, those patients eating unwashed vegetables are 2.26 times ( $\mathrm{AOR}=2.26 ; 95 \% \mathrm{Cl}$ : 1.052-4.843; $p$ value $=0.021)$ more likely to have parasite than those consuming unwashed raw vegetables (Table-4).

Table-1: Prevalence of intestinal parasites in relation with socio-demographic characteristics of HIV/AIDS infected patients $(\mathrm{N}=191)$ 


\section{Characteristics}

Total N

(\%)
Parasitic infections

Positive N Negative N

(\%)

(\%)
$\operatorname{COR}(95 \% \mathrm{Cl})$

$P$-value

\section{Age groups}

\begin{tabular}{llllll}
$15-34$ & $67(35.1)$ & $24(35.8)$ & $43(34.7)$ & $0.99(0.333-2.524)$ & 0.990 \\
$35-50$ & $89(46.6)$ & $31(46.3)$ & $58(46.8)$ & $\begin{array}{l}1.16(0.4398- \\
3.356)\end{array}$ & 0.789 \\
\hline 50 & $35(18.3)$ & $12(17.9)$ & $23(18.5)$ & Ref &
\end{tabular}

\section{Gender}

Male

$78(40.8) \quad 31(46.3)$

47(37.9)

Female

113 (59.2) $36(53.7)$

77 (62.1)

$1.41(0.773-2.575)$

0.262

\section{Residence}

Urban

103 (53.9) $35(52.2)$

$88(46.1) \quad 32(47.8)$

68 (54.8)

Ref

Rural

Marital status

Married

133 (69.6) 41(61.2)

92 (74.2)

$32(25.8)$

Ref

Single

$58(30.4) \quad 26(38.8)$

$56(45.2)$

$0.39(0.205-0.755)^{\star} \quad 0.005$

\section{Educational}

Status

\begin{tabular}{|llllll} 
Illiterate & $14(7.3)$ & $4(6.0)$ & $10(8.1)$ & $2.11(0.141-31.587)$ & 0.587 \\
\hline Read and write & $41(21.5)$ & $15(22.4)$ & $26(21.0)$ & $\begin{array}{l}2.19(0.115- \\
41.600)\end{array}$ & 0.603 \\
\hline Primary school & $65(34.0)$ & $23(34.3)$ & $42(33.9)$ & $0.89(0.130-6.059)$ & 0.902 \\
\hline Secondary school & $53(27.7)$ & $19(28.4)$ & $34(27.4)$ & $1.04(0.140-7.689)$ & 0.971 \\
\hline College and above & $18(9.4)$ & $6(9.0)$ & $12(9.7)$ & Ref & \\
\hline Occupation & & & & & \\
\hline Gov't employer & $27(14.1)$ & $8(11.90$ & $19(15.3)$ & Ref & 0.447 \\
\hline Farmer & $36(18.8)$ & $14(20.9)$ & $22(17.7)$ & $0.66(0.228-1.917)$ & 0.697 \\
\hline House wife & $44(23.0)$ & $15(22.4)$ & $29(23.4)$ & $0.81(0.289-2.291)$ & 0.640 \\
\hline Merchants & $34(17.8)$ & $12(17.9)$ & $22(17.7)$ & $0.77(0.261-2.284)$ & 0.669 \\
\hline Student & $9(4.7)$ & $2(3.0)$ & $7(5.6)$ & $1.47(0.250-8.698)$ & 0.47 \\
\hline
\end{tabular}


Table 2: Prevalence of intestinal parasites in relation with ART status

\begin{tabular}{|c|c|c|c|c|}
\hline \multirow[t]{2}{*}{ Parasites detected } & \multicolumn{2}{|l|}{ ART status } & \multirow{2}{*}{$\begin{array}{l}\text { Chi-square ( } \\
\left.\mathrm{X}^{2}\right)\end{array}$} & \multirow[t]{2}{*}{$P$-value } \\
\hline & $\begin{array}{l}\text { On-ART N } \\
(\%)\end{array}$ & $\begin{array}{l}\text { ART naïve group } N \\
(\%)\end{array}$ & & \\
\hline $\begin{array}{l}\text { Entamoeba } \\
\text { histolytica/dispar }\end{array}$ & $11(7.7)$ & $6(12.5)$ & 1.999 & 0.157 \\
\hline Giardia lamblia & $10(7.0)$ & $5(10.4)$ & 0.582 & 0.445 \\
\hline Ascaris lumbricoides & $9(6.3)$ & $3(6.25)$ & 0.00 & 0.991 \\
\hline Cryptosporidium spps & $2(1.4)$ & $2(4.2)$ & 1.343 & 0.247 \\
\hline Isospora belli & 0 & $1(2.1)$ & 2.995 & 0.084 \\
\hline Trichuris trichiuria & $4(2.8)$ & $2(4.2)$ & 0.603 & 0.437 \\
\hline Hymenolepis nana & $2(1.4)$ & 0 & 0.678 & 0.410 \\
\hline Schistosoma mansoni & $4(2.8)$ & $2(4.2)$ & 0.603 & 0.437 \\
\hline Strongyloides stercolaris & $1(0.7)$ & 0 & 0.337 & 0.561 \\
\hline Hook worm & $1(0.7)$ & $1(2.1)$ & 0 & 0.440 \\
\hline Taenia spps & $1(0.7)$ & 0 & 0 & 1.000 \\
\hline Double infections & $3(2.1)$ & $2(4.2)$ & - & - \\
\hline Total & $45(31.5)$ & $22(45.8)$ & 3.256 & 0.071 \\
\hline
\end{tabular}

Table-3: Prevalence of intestinal parasites in relation with CD4 level, viral load, ART status and WHO stages of HIV/AIDS patients 


\begin{tabular}{|c|c|c|c|c|c|c|}
\hline \multirow[t]{2}{*}{ Variables } & \multirow{2}{*}{$\begin{array}{l}\text { Total N } \\
\text { (\%) }\end{array}$} & \multicolumn{2}{|c|}{ Intestinal parasites } & \multirow[t]{2}{*}{$\operatorname{COR}(95 \% \mathrm{Cl})$} & \multirow[t]{2}{*}{ AOR (95\% Cl) } & \multirow{2}{*}{$\begin{array}{l}P \\
\text { value }\end{array}$} \\
\hline & & $\begin{array}{l}\text { Positives N } \\
(\%)\end{array}$ & $\begin{array}{l}\text { Negatives N } \\
(\%)\end{array}$ & & & \\
\hline \multicolumn{7}{|l|}{ CD4 levels } \\
\hline$<200$ cell $/ \mathrm{mm}^{3}$ & $15(7.9)$ & $8(11.9)$ & $7(5.7)$ & $\begin{array}{l}0.31(0.100- \\
0.934)\end{array}$ & $\begin{array}{l}0.22(0.062- \\
0.798)\end{array}$ & 0.021 \\
\hline $\begin{array}{l}200- \\
500 \mathrm{cell} / \mathrm{mm}^{3}\end{array}$ & $\begin{array}{l}87 \\
(45.5)\end{array}$ & $36(53.7)$ & $51(41.1)$ & $\begin{array}{l}0.49(0.261- \\
0.935)\end{array}$ & $\begin{array}{l}0.40(0.195- \\
0.811)\end{array}$ & 0.011 \\
\hline$>500$ cell $/ \mathrm{mm}^{3}$ & $\begin{array}{l}89 \\
(46.6)\end{array}$ & $23(34.30$ & $66(53.2)$ & Ref & Ref & \\
\hline \multicolumn{7}{|l|}{ ART status } \\
\hline On ART & $\begin{array}{l}143 \\
(74.9)\end{array}$ & $45(67.2)$ & $98(79.0)$ & Ref & & \\
\hline ART naïve & $\begin{array}{l}48 \\
(25.1)\end{array}$ & $22(32.8)$ & $26(21.0)$ & $\begin{array}{l}0.54(0.278- \\
1.059)\end{array}$ & - & 0.071 \\
\hline \multicolumn{7}{|l|}{ Viral load } \\
\hline $\begin{array}{l}<150 \\
\text { copies/ml }\end{array}$ & $\begin{array}{l}129 \\
(67.5)\end{array}$ & $37(55.2)$ & $92(74.2)$ & Ref & Ref & \\
\hline $\begin{array}{l}\geq 150 \\
\text { copies } / \mathrm{ml}\end{array}$ & $\begin{array}{l}62 \\
(32.5)\end{array}$ & $30(44.8)$ & $32(25.8)$ & $\begin{array}{l}0.43(0.229- \\
0.843)^{\star}\end{array}$ & $\begin{array}{l}0.44(0.220- \\
0.873)^{*}\end{array}$ & 0.019 \\
\hline \multicolumn{7}{|l|}{ WHO stage } \\
\hline Stage I & $\begin{array}{l}96 \\
(50.3)\end{array}$ & $21(31.3)$ & $75(60.5)$ & Ref & Ref & \\
\hline Stage II & $\begin{array}{l}75 \\
(39.3)\end{array}$ & $36(53.7)$ & $39(31.5)$ & $\begin{array}{l}0.35(0.170- \\
0.706)^{\star}\end{array}$ & $\begin{array}{l}0.30(0.156- \\
0.589)^{\star}\end{array}$ & 0.001 \\
\hline Stage III & $17(8.9)$ & 8 (11.9) & $9(7.2)$ & $\begin{array}{l}0.28(0.088- \\
0.853)^{\star}\end{array}$ & $\begin{array}{l}0.32(0.108- \\
0.917)^{\star}\end{array}$ & 0.034 \\
\hline Stage IV & $3(1.8)$ & $2(3.0)$ & $1(0.8)$ & $\begin{array}{l}0.22(0.016- \\
3.166)\end{array}$ & $\begin{array}{l}0.14(0.012- \\
1.620)\end{array}$ & 0.116 \\
\hline
\end{tabular}

NB: *: statistical significance association; Ref: Reference categories

Table- 4: Prevalence of intestinal parasites among HIV positive patients with regard to their environmental conditions and hygienic practices $(\mathrm{N}=191)$ 


\begin{tabular}{|c|c|c|c|c|c|c|}
\hline \multirow[t]{2}{*}{ Variables } & \multirow{2}{*}{$\begin{array}{l}\text { Total } \\
\text { N (\%) }\end{array}$} & \multicolumn{2}{|c|}{ Parasitic Infections } & \multirow{2}{*}{$\begin{array}{l}\text { COR }(95 \% \\
\mathrm{Cl})\end{array}$} & \multirow{2}{*}{$\begin{array}{l}\text { AOR }(95 \% \\
\text { Cl) }\end{array}$} & \multirow{2}{*}{$\begin{array}{l}P \\
\text { value }\end{array}$} \\
\hline & & $\begin{array}{l}\text { Positive } \\
\text { N (\%) }\end{array}$ & $\begin{array}{l}\text { Negative } \\
\mathrm{N}(\%)\end{array}$ & & & \\
\hline \multicolumn{7}{|l|}{ Presence of toilet } \\
\hline Yes & $\begin{array}{l}180 \\
(94.2)\end{array}$ & $\begin{array}{l}64 \\
(95.5)\end{array}$ & $\begin{array}{l}116 \\
(93.6)\end{array}$ & Ref & & \\
\hline No & $\begin{array}{l}11 \\
(5.8)\end{array}$ & $3(4.5)$ & $8(6.4)$ & $\begin{array}{l}1.47(0.377- \\
5.741)\end{array}$ & - & 0.259 \\
\hline \multicolumn{7}{|l|}{$\begin{array}{l}\text { Eating meal without } \\
\text { hand washing }\end{array}$} \\
\hline Yes & $9(4.7)$ & $2(3.0)$ & $7(5.6)$ & $\begin{array}{l}1.94(0.392- \\
9.635)\end{array}$ & - & 0.180 \\
\hline No & $\begin{array}{l}182 \\
(95.3)\end{array}$ & $\begin{array}{l}65 \\
(97.0)\end{array}$ & $\begin{array}{l}117 \\
(94.4)\end{array}$ & Ref & & \\
\hline \multicolumn{7}{|l|}{ Source of water } \\
\hline Tape water & $\begin{array}{l}171 \\
(89.5)\end{array}$ & $\begin{array}{l}59 \\
(88.1)\end{array}$ & $\begin{array}{l}112 \\
(90.3)\end{array}$ & Ref & & \\
\hline River/spring water & $\begin{array}{l}20 \\
(10.5)\end{array}$ & $8(11.9)$ & $12(9.7)$ & $\begin{array}{l}0.79(0.306- \\
2.040)\end{array}$ & - & 0.626 \\
\hline \multicolumn{7}{|l|}{$\begin{array}{l}\text { Treatment of water } \\
\text { before drinking }\end{array}$} \\
\hline Yes & $\begin{array}{l}16 \\
(8.4)\end{array}$ & $1(1.5)$ & $15(12.1)$ & Ref & Ref & \\
\hline No & $\begin{array}{l}175 \\
(91.6)\end{array}$ & $\begin{array}{l}66 \\
(98.5)\end{array}$ & $\begin{array}{l}109 \\
(87.9)\end{array}$ & $\begin{array}{l}0.11(0.014- \\
0.853)^{\star}\end{array}$ & $\begin{array}{l}0.13(0.016- \\
1.012)^{\star}\end{array}$ & 0.035 \\
\hline \multicolumn{7}{|l|}{$\begin{array}{l}\text { Contact with animal } \\
\text { feaces }\end{array}$} \\
\hline Yes & $\begin{array}{l}55 \\
(28.8)\end{array}$ & $\begin{array}{l}16 \\
(23.9)\end{array}$ & $39(31.4)$ & $\begin{array}{l}0.68(0.347- \\
1.346)\end{array}$ & - & 0.160 \\
\hline No & $\begin{array}{l}136 \\
(71.2)\end{array}$ & $51(76.1)$ & $85(68.6)$ & Ref & & \\
\hline \multicolumn{7}{|l|}{ Consuming raw food } \\
\hline Yes & $\begin{array}{l}181 \\
(94.8)\end{array}$ & $\begin{array}{l}66 \\
(98.5)\end{array}$ & $\begin{array}{l}115 \\
(92.7)\end{array}$ & $\begin{array}{l}0.63(0.563- \\
0.704)^{\star}\end{array}$ & $\begin{array}{l}0.23(0.025- \\
2.108)^{\star}\end{array}$ & 0.017 \\
\hline No & $\begin{array}{l}10 \\
(5.2)\end{array}$ & $1(1.5)$ & $9(7.3)$ & Ref & Ref & \\
\hline $\begin{array}{l}\text { Habit of eating } \\
\text { unwashed vegetables }\end{array}$ & & & & & & \\
\hline
\end{tabular}




\begin{tabular}{|c|c|c|c|c|c|c|}
\hline Yes & $\begin{array}{l}38 \\
(19.9)\end{array}$ & $\begin{array}{l}20 \\
(29.8)\end{array}$ & $18(14.5)$ & $\begin{array}{l}2.51(1.215- \\
5.166)^{*}\end{array}$ & $\begin{array}{l}2.26(1.052- \\
4.843)^{*}\end{array}$ & 0.021 \\
\hline No & $\begin{array}{l}153 \\
(80.1)\end{array}$ & $\begin{array}{l}47 \\
(70.2)\end{array}$ & $\begin{array}{l}106 \\
(85.5)\end{array}$ & Ref & Ref & \\
\hline \multicolumn{7}{|c|}{$\begin{array}{l}\text { Contact with any water } \\
\text { body }\end{array}$} \\
\hline Yes & $\begin{array}{l}48 \\
(25.1)\end{array}$ & $\begin{array}{l}14 \\
(20.9)\end{array}$ & $34(27.4)$ & $\begin{array}{l}0.70(0.344- \\
1.421)\end{array}$ & - & 0.321 \\
\hline No & $\begin{array}{l}143 \\
(74.9)\end{array}$ & $\begin{array}{l}53 \\
(79.1)\end{array}$ & $90(72.6)$ & Ref & & \\
\hline \multicolumn{7}{|c|}{$\begin{array}{l}\text { Habit of walking on bare } \\
\text { foot }\end{array}$} \\
\hline Yes & $\begin{array}{l}17 \\
(8.9)\end{array}$ & 7 (10.4) & $10(8.1)$ & $\begin{array}{l}1.33(0.482- \\
3.671)\end{array}$ & - & 0.581 \\
\hline No & $\begin{array}{l}174 \\
(91.1)\end{array}$ & $\begin{array}{l}60 \\
(89.6)\end{array}$ & $\begin{array}{l}114 \\
(91.9)\end{array}$ & Ref & & \\
\hline
\end{tabular}

NB: *: statistical significance association; Ref: Reference categories

\section{Discussion}

This study was a hospital based cross- sectional study which was conducted to assess the prevalence of intestinal parasites among HIV/AIDS patients at southwest district of Ethiopia. Accordingly, the overall prevalence of intestinal parasites was $35.1 \%$ which was higher than study findings in different parts of Ethiopia in which the average prevalence of intestinal parasites among HIV/AIDS patients was $18.2 \%$ [20-23]. However, this finding is lower than a finding in Nekemte (73.3\%) [24], Gondar (45.3\%) [25], Ethiopia. As compared with other developing countries, this finding is higher than a study finding in Mozambique (26.4\%) [26], India (27.6\%) [27] and Colombia (29.2\%) [28]; however, lowers than study findings in Nigeria (68.2\%) [29], Gabon (42.6\%) [30], Cameroon (57.5\%) [31] and Kenya (50.9\%) [32]. The observed variations may be explained by the difference in geographic location, the difference in sample size, awareness and hygienic practices of the population in the preventions of intestinal parasite infections and moreover the variation in immune status of the study participants. In addition, the observed variations may be influenced by study period in which nowadays there is a better awareness of the patients about intestinal parasite infection and their cause.

In this study, the prevalence of intestinal parasite among ART and ART naïve group was (31.5\%) and (45.8\%) which was in line with study finding in Northern Ethiopia, Dessie and Gondar, in which the higher proportion of intestinal parasite were observed in ART naïve group [21,25]. This higher prevalence in ART naïve group might be explained by the immune status of the study participants. In fact, ART improving the quality of life and reducing the occurrence of opportunistic infection due to immuno suppression. In addition, ART patients might be followed through laboratory screening for intestinal parasites and may 
get deworming and better awareness in adopting prevention and treatment measures against intestinal parasites.

Although there is no statistical significant difference in the overall detected parasitic species between ART and ART naïve group, Entamoeba histolytica/disparand Giardia lamblia was the most predominant parasites detected both in ART and ART naïve groups in this study. However, the prevalence of Cryptosporidium spps in ART and ART naïve groups was $1.4 \%$ and $4.2 \%$, respectively. This finding is in line with other study finding in Ethiopia [17, 21, 25] and Colombia [28], in which higher predominance of non-opportunistic intestinal parasites were reported. The higher proportion of non-opportunistic intestinal parasites indicates that, ART may also be contributed to the reduction of opportunistic intestinal parasites infections.

In this study, intestinal parasitic infections occurrence was significantly higher in patients with $\mathrm{CD}_{4}$ count $<200 \mathrm{cell} / \mathrm{mm}^{3}$, which is in line with other study findings [20-25,33]. Unlike others, in our study the occurrence of intestinal parasitic infections was also significantly higher in patients with $\mathrm{CD}_{4}$ count 200$500 \mathrm{cell} / \mathrm{mm}^{3}$. However, other study in Ethiopia reported that $\mathrm{CD}_{4}$ count $<500 \mathrm{cell} / \mu \mathrm{l}$ was significantly associated with opportunistic intestinal parasitic infections [34]. In fact, immuno-deficient patients are more vulnerable in acquiring intestinal parasites and are unable to clear the infection once it is established $[33,35]$.

In this study, being WHO stage II and III were also significantly associated with intestinal parasitic infection. The occurrence higher intestinal parasitic infection in patients with WHO stage III was in line with other study finding [21,36]. Similarly, in this study, viral load $\geq 150$ copies/ml was also significantly associated with intestinal parasitic infection, which also is reported in other study [22]. The higher the viral load, may be related with low level of CD4 count and advanced WHO stage, which leads to the quicker a person's immune system will be damaged, increasing their chances of catching infections that the body would normally fight off very easily. Some studies reported that, baseline CD4 count of $500 \mathrm{cells} / \mu \mathrm{l}$ or more was significantly associated with viral load reductions or suppression [37-39].

In this study, environmental and hygienic practices of study participants like drinking untreated water, consuming raw food and eating unwashed raw vegetables were found to be significantly associated with intestinal parasitic infections. Significant association of consuming raw unwashed raw vegetables and drinking untreated water with intestinal parasitosis is also reported in other studies in Ethiopia [17, 23, 40]. Therefore, a combination of public health and clinical strategies is required in the prevention and control of intestinal parasites. The efforts should be focused not only on the treatment of infected individuals but also on the other contributing risk factors.

In this study, only saline and iodine wet mount, formol-ether concentration and modified Ziehl-Neelsen staining method was used for the detection of intestinal parasites. Thus the added yield of intestinal parasites may be an underestimate as we have not used water-ether sedimentation method for Microsporidia and other methods like molecular techniques and immuno flouscent techniques which are 
sensitive for parasites. In addition, patients may be got deworming and/or diagnosed for parasites and treated as well before.

\section{Conclusion}

In this present study, high prevalence of intestinal parasites among HIV infected patient in was observed. Higher rate of intestinal parasitosis were associated with hygienic practices like drinking untreated water, consuming raw food and eating unwashed raw vegetables and with some clinical findings such as lower CD4 counts, increased viral load and being WHO stage II \& III. Increasing accessibility of antiretroviral therapy for HIV infected patients may help to reduce or suppress the viral load to lower or an undetectable level and boost the immune status in reducing vulnerability of the patients for acquisition of intestinal parasites. In addition, utilization of water treating chemicals and stool examination in the follow-up of patients with HIV/AIDS attending ART clinic and raising awareness about the prevention and control of intestinal parasites and prompt treatment are necessary.

\section{Abbreviations}

AIDS: Acquired Immuno Deficiency Syndrome, ART: Anti-Retroviral Treatment, $\mathbf{C D}_{\mathbf{4}}$ : Cluster differentiation, HIV: Human immunodeficiency Virus, IP:-Intestinal parasite

\section{Declarations}

\section{Ethical approval and consent to participate}

Ethical approval was obtained first from Mizan- Tepi University Ethical committee. Legal permission was obtained from hospital administrative (COE). Informed consent was obtained from the parents for the study participation. All methods were performed in accordance with the relevant guidelines and regulations.

\section{Consent for publications}

"Not applicable”

\section{Availability of data and materials}

"All the data supporting our findings were incorporated within the manuscript".

\section{Competing Interests}

"The authors declare that they have no competing interest". 


\section{Authors' contributions}

Both authors were participated in the study design and recruitment. $M A^{*}$ analyzed the data and drafted the manuscript. All the authors have contributed to the manuscript and approved the final version.

\section{Funding}

"No funding was allocated for this study"

\section{Acknowledgement}

First, we would like to thanks Mizan-Tepi University, Institute of Research and Community Support Coordinating Office. Thanks to all data collectors for their willingness during data collection.

\section{References}

1. Faria CP, Zanini GM, Dias GS, da Silva S, de Freitas MB, Almendra R, et al. Geospatial distribution of intestinal parasitic infections in Rio de Janeiro (Brazil) and its association with social determinants. PLoS neglected tropical diseases. 2017; 11(3):e0005445. https://doi.org/10.1371/journal.pntd.0005445.

2. Speich B, Croll D, Fu"rst T, Utzinger J, Keiser J. Effect of sanitation and water treatment on intestinal protozoa infection: a systematic review and meta-analysis. The Lancet Infectious Disease. 2016; 16 (1):87-99. https://doi.org/10.1016/S1473-3099(15)00349-7.

3. Teklemariam $\mathrm{Z}<\mathrm{bi} i,</ \mathrm{bi}>$ Abate $\mathrm{D}<\mathrm{bi} i,</ \mathrm{bi}>\mathrm{Mitiku} \mathrm{H}<\mathrm{bi},,</ \mathrm{bi}>$ Dessie $\mathrm{Y}<\mathrm{bi}>$. Prevalence of intestinal parasitic infection among HIV positive persons who are naïve and on antiretroviral treatment in Hiwot Fana Specialized University Hospital, Eastern Ethiopia. ISRN AIDS.</bi> 2013<bi>; 2013:1-6. doi: $</$ bi $>$

10

$.1155 / 2013 / 324329<\mathrm{bi}>.</ \mathrm{bi}>$

4. OguntibejuOO Prevalence of intestinal parasites in HIV - positive /AIDS patients in sout Africa. Malaysian Journal of Medical Sciences.2006; 13(1):68-73.

5. Nelson, M. Gantz. Manual of clinical problems in infectious disease. /Nelson [etal] -3rd ed. 1998; p 435-437 and $440-44$

6. Dirk Engels and Xiao-Nong Zhou. Neglected tropical diseases: an effective global response to local poverty-related disease priorities. Infectious Diseases of Poverty.2020; 9:10.

https://doi.org/10.1186/s40249-020-0630-9.

7. Ochola EA, Karanja DMS, Elliott SJ. The impact of Neglected Tropical Diseases (NTDs) on health and wellbeing in sub-Saharan Africa (SSA): A case study of Kenya. PLoS Negl Trop Dis. 2021; 15(2): e0009131. https://doi.org/10.1371/journal.pntd.0009131. 
8. World Health Organization. Working to Overcome the Global Impact of Neglected Tropical Diseases. Geneva: WHO; 2010

9. World Health Organization. (2013). Sustaining the drive to overcome the global impact of neglected tropical diseases: second WHO report on neglected tropical diseases: summary? World Health Organization. https://apps.who.int/iris/handle/10665/80245

10. Deribe K, Meribo K, Gebre T, Hailu A, Ali A, Aseffa A, et al. The burden of neglected tropical diseases in Ethiopia, and opportunities for integrated control and elimination. Parasites \& vectors. 2012; 5(1):240.

11. Hotez PJ, Kamath A. Neglected tropical diseases in sub-Saharan Africa: review of their prevalence, distribution, and disease burden. PLoS Negl Trop Dis. 2009; 3(8):e412. https://doi.org/10.1371/journal.pntd.0000412.

12. Alemu1G, Abossie A and Yohannes Z. Current status of intestinal parasitic infections and associated factors among primary school children in Birbir town, Southern Ethiopia<bi $></$ bi $>\mathrm{BMC}$ Infectious Diseases. 2019; 19: 270. https://doi.org/10.1186/s12879-019-3879-5.

13. Eyayu T, Kiros T, Workineh L, Sema M, Damtie S, Hailemichael W, et al. Prevalence of intestinal parasitic infections and associated factors among patients attending at Sanja Primary Hospital, Northwest Ethiopia: An institutional-based cross-sectional study. PLoS ONE. 2021; 16(2): e0247075. https://doi.org/10.1371/journal.pone.0247075.

14. Gebretsadik D, Tesfaye M, Adamu A and Zewde G. Prevalence of intestinal parasitic infection and its associated factors among school children in two primary schools in Harbu town, North East Ethiopia: Cross-sectional study. Pediatric Health, Medicine and Therapeutics. 2020:11 179-188. http://doi.org/10.2147/PHMT.S252061.

15. Tigabu, A., Taye, S., Aynalem, M. et al. Prevalence and associated factors of intestinal parasitic infections among patients attending Shahura Health Center, Northwest Ethiopia. BMC Res Notes. 2019; 12, 333 (2019). https://doi.org/10.1186/s13104-019-4377-y.

16. Wondmieneh A, Gedefaw G, Alemnew B, Getie A, Bimerew M, Demis A. Intestinal parasitic infections and associated factors among people living with HIV/AIDS in Ethiopia: A systematic review and meta-analysis. PLoS ONE. 2020; 15(12): e0244887. https://doi.org/10.1371/journal.pone.0244887.

17. Gebretsadik, D., Haileslasie, H. \& Feleke, D.G. Intestinal parasitosis among HIV/AIDS patients who are on anti-retroviral therapy in Kombolcha, North Central, Ethiopia: a cross-sectional study. BMC Res Notes 11, 613 (2018). https://doi.org/10.1186/s13104-018-3726-6

18. Ritchie LS. An ether sedimentation technique for routine stool examinations. Bulletin of the US Army Medical Department. 1948; 8(4):326.

19. Henriksen SA, Pohlenz JF. Staining of Cryptosporidia by a modified Ziehl-Neelsen technique. Acta Veterinaria Scandinavica. 1981; 22(3-4):594-596.

20. Alemayehu E, Gedefie A, Adamu A, et al. Intestinal parasitic infections among HIV-infected patients on antiretroviral therapy attending Debretabor general hospital, Northern Ethiopia: A Cross-sectional study. HIV AIDS (Auckl). 2020; 12: 647-655. doi:10.2147/HIV.S275358 
21. Missaye, A., Dagnew, M., Alemu, A. et al. Prevalence of intestinal parasites and associated risk factors among HIV/AIDS patients with pre-ART and on-ART attending Dessie hospital ART clinic, Northeast Ethiopia. AIDS Res Ther 10, 7 (2013). https://doi.org/10.1186/1742-6405-10-7

22. Bayleyegn B, Woldu B, Yalew A, Kasew D, Asrie F. Prevalence of Intestinal Parasitic Infection and Associated Factors Among HAART Initiated Children Attending at University of Gondar Comprehensive Specialized Hospital, Northwest Ethiopia. HIV AIDS (Auckl). 2021 Jan 25; 13: 81-90. doi: 10.2147/HIV.S287659. PMID: 33531842; PMCID: PMC7846865.

23. Gebrewahid, T., Gebrekirstos, G., Teweldemedhin, M. et al. Intestinal parasitosis in relation to CD4 count and anemia among ART initiated patients in St. Mary Aksum general hospital, Tigray, Ethiopia. BMC Infect Dis 19, 350 (2019). https://doi.org/10.1186/s12879-019-3989-0

24. Miressa R, Dufera M. Prevalence and Predisposing Factors of Intestinal Parasitic Infections Among HIV Positive Patients Visiting Nekemte Specialized Hospital, Western Ethiopia. HIV AIDS (Auckl). 2021 May 14; 13: 505-512. doi: 10.2147/HIV.S304294. PMID: 34017200; PMCID: PMC8131008.

25. Gebrecherkos T, Kebede $H$ and Gelagay AA. Intestinal parasites among HIV/AIDS patients attending University of Gondar Hospital, northwest Ethiopia. J. Health Dev. 2019; 33(2)

26. Cerveja BZ, Tucuzo RM, Madureira AC, Nhacupe N, Langa IA, Buene T, Banze L, Funzamo C, Noormahomed EV. Prevalence of Intestinal Parasites Among HIV Infected and HIV Uninfected Patients Treated at the $1^{\circ}$ De Maio Health Centre in Maputo, Mozambique. EC Microbiol. 2017; 9(6):231-240. Epub 2017 Jul 20. PMID: 29911204; PMCID: PMC5999047.

27. Chhangte MZ, Koticha A, Ingole N, et al. Prevalence of intestinal parasites in HIV sero-positive patients attending an integrated counseling and testing centre. J. Evolution Med. Dent. Sci. 2020;9(12): 919-923, DOI: 10.14260/jemds/2020/198

28. Botero JH, Villegas-Arbeláez E, Giraldo S, UránVelásquez J, Arias-Agudelo L, Alzate JC, et al. Prevalence of intestinal parasites in a cohort of HIV-infected patients from Antioquia, Colombia. Biomédica. 2021; 41(Supl.2):153-64. https://doi.org/10.7705/biomedica.5992

29. O.A. Obateru, B.J. Bojuwoye, A.B. Olokoba, A. Fadeyi, A. Fowotade, L.B. Olokoba. Prevalence of intestinal parasites in newly diagnosed HIV/AIDS patients in llorin, Nigeria. Alexandria Journal of Medicine. Volume 53, Issue 2, 2017, Pages 111-116, ISSN 2090-5068, https://doi.org/10.1016/j.ajme.2016.04.001.

30. Lengongo JVK, Ngondza BP, Ditombi BM, M'Bondoukwé NP, Ndong Ngomo JM, Delis AM, et al. Prevalence and associated factors of intestinal parasite infection by HIV infection status among asymptomatic adults in rural Gabon. Afri Health Sci. 2020; 20(3): 1024-1034. https://dx.doi.org/10.4314/ahs.v20i3.5

31. Vouking MZ, Enoka P, Tamo CV, Tadenfok CN. Prevalence of intestinal parasites among HIV patients at the Yaoundé Central Hospital, Cameroon. Pan Afr Med J. 2014; 18: 136. Published 2014 Jun 11. doi:10.11604/pamj.2014.18.136.3052

32. Kipyegen CK, Shivairo RS, Odhiambo RO. Prevalence of intestinal parasites among HIV patients in Baringo, Kenya. Pan African Medical Journal. 2012;13(1). 
33. Gupta K, Bala M, Deb M, Muralidhar S, Sharma DK. Prevalence of intestinal parasitic infections in HIV-infected individuals and their relationship with immune status. Indian J Med Microbiol. 2013 AprJun; 31(2):161-5. doi: 10.4103/0255-0857.115247. PMID: 23867673.

34. Getaneh Alemu, Dagninet Alelign, Ashenafi Abossie. Prevalence of Opportunistic Intestinal Parasites and Associated Factors among HIV Patients while Receiving ART at Arba Minch Hospital in South Ethiopia: A Cross-sectional Study. Ethiop J Health Sci.2018; 28(2):147. doi: http://dx.doi.org/10.4314/ejhs.v28i2.6

35. Evering T, Weiss $L$. The immunology of parasite infections in immunocompromised hosts. Parasite Immunol. 2006; 28(11):549-565. doi:10.1111/j.1365-3024.2006.00886.x

36. Dufera M, Petros B, Endeshaw T, Mohammed H, Kassu A: Opportunistic intestinal protozoan parasites among HIV positive patients on antiretroviral therapy at Nekemte hospital, West Ethiopia. Ethiop J Health Biomed Sci 2008, 1(Suppl 1):11-17. 23.

37. Abdullahi, S.B., Ibrahim, O.R., Okeji, A.B. et al. Viral suppression among HIV-positive patients on antiretroviral therapy in northwestern Nigeria: an eleven-year review of tertiary care centre records, January 2009-December 2019. BMC Infect Dis 21, 1031 (2021). https://doi.org/10.1186/s12879021-06722-3

38. Wakooko P, Gavamukulya Y, Wandabwa JN. Viral load Suppression and Associated Factors among HIV Patients on Antiretroviral Treatment in Bulambuli District, Eastern Uganda: A Retrospective Cohort Study. Infect Dis (Auckl). 2020 Nov 5; 13: 1178633720970632. doi:

$10.1177 / 1178633720970632$

39. Pius, A., Josephine, N.N., Erick, S. et al. Influence of intensified adherence counseling on viral load suppression of people receiving antiretroviral therapy at a health centre IV in southwestern Uganda: a qualitative study. AIDS Res Ther 18, 45 (2021). https://doi.org/10.1186/s12981-021-00372-w .

40. Feleke BE, Beyene MB, Feleke TE, JemberTH, Abera B. Intestinal parasitic infection among household contacts of primary cases, a comparative cross-sectional study. PLoS ONE. 2019; 14 (10): e0221190. https://doi.org/10.1371/journal.pone.0221190.

41. Zida A, Yacouba A, Sawadogo MP, Diallo I, Sangare I, et al. Opportunistic and other intestinal parasites infections among HIV-positive patients in the era of combination antiretroviral therapy and preventive treatment in Ouagadougou, Burkina Faso. J HIV Clin Sci Res. 2017; 4(1): 008-014. DOI: http://doi.org/10.17352/2455-3786.000122. 